\title{
Between trust and violence: medical encounters under Japanese military occupation during the War in China (1937-1945)
}

\author{
Reut Harari* \\ East Asian Studies Department, Tel Aviv University, P.O. Box 39040, Ramat Aviv, Tel Aviv 6139001, Israel \\ ${ }^{\star}$ Corresponding author. Email: reutharari@tauex.tau.ac.il
}

\begin{abstract}
During the War in China (1937-1945), the Japanese military combined warfare with the maintenance of a military occupation. To sustain its tentative grasp over the occupied territories, the Japanese military vied to cultivate trust among the local population. This was a challenging task in the midst of a violent war which as many historical works described was accompanied by brutal war crimes. A less explored aspect of the occupation was medical care. This article unfolds this history by analysing medical encounters between Japanese military medics and military affiliated agents, and members of the local population in the rural Chinese countryside. Testimonies reveal that these encounters - some spontaneous and others deliberate - were small moments of humanity and benevolence within a violent environment. Concomitantly, they demonstrate the overarching tension in this unequal encounter and the use of medicine as a pacifying tool that also served as means to build and maintain the occupation through the transference of medical trust towards the military at large. Thus, this article presents a different aspect of the role of trust and distrust in medical care, as well as expanding the analysis of medicine as a 'tool of empire' to the context of military occupation.
\end{abstract}

Keywords: Military medicine; Imperial medicine; Military occupation; Trust; Japan; China

\section{Introduction}

At the heart of medical practice lies the human encounter between those who provide care and those who need care. This encounter yields a relationship of a delicate nature, built upon trust. Disease and physical harm make the weaker patient dependent upon the stronger caregiver, who is to guide the patient back to 'the kingdom of the well', as Susan Sontag famously put it. ${ }^{1}$ Yet, the vulnerable patient has agency in a number of crucial ways, grounded in the ability and willingness to enter into this relationship in the first place and subsequently to commit to it. History reveals that this readiness depends on a myriad of factors, such as socio-economic background, age, gender, class, historical context and the changing nature of medical care, knowledge and practice. ${ }^{2}$ Trust - as varied and intangible as it is - underpins medical encounters and care and is the focus of this article.

What happens to trust and the medical relationship when the care provider belongs to an occupying military force and the patient to the occupied population? What role does trust play in a medical relationship formed within the violent context of war? These questions bring to the fore trust's

\footnotetext{
${ }^{1}$ Susan Sontag, Illness as Metaphor (New York: Farrar, Strauss and Giroux, 1978), 3.

${ }^{2}$ This issue comes up in many works on the history of disease, the medical marketplace and the doctor-patient relationship. See, for instance: Chris Feudtner, Bittersweet: Insulin and the Transformation of Illness (Chapel Hill: The University of North Carolina Press, 2003); Jonathan B. Imber, Trusting Doctors (Princeton: Princeton University Press, 2008); N.D. Jewson, 'The Disappearance of the Sick-man from Medical Cosmology, 1770-1870', Sociology, 10 (1976), 225-44; Roy Porter (ed.), Patients and Practitioners (Cambridge: Cambridge University Press, 1985).
}

(c) The Author(s), 2020. Published by Cambridge University Press. 
inseparable counterpart - distrust. In the case of military occupation, trust and distrust take on added significance. The military brings the caregiver and patient together but often imposes barriers, suspicion and tension on the medical encounter. This article examines the resulting ambiguous relationship in a historical case where the boundaries between trust and distrust were often murky and where violence and fear were particularly prevalent: the Japanese occupation of China during the late 1930s and 1940s.

From the late nineteenth century and up to the beginning of the War in China (1937-45), ${ }^{3}$ the Japanese empire spread considerably, starting with Taiwan and Korea and then expanding into Manchuria and northern China. By 1937, Chinese Nationalist and Communist forces reached an agreement to cooperate against Japan, leading to fierce battles and guerrilla warfare, the likes of which the Japanese military did not face in China before. ${ }^{4}$ During the war, Japanese military forces moved into new regions - deeper into the north, as well as central and southern China, encountering new terrain and populations. Yet China was not a colony or annexed territory, the nature of Japanese rule was throughout that of a precarious military occupation. ${ }^{5}$

Previous research has demonstrated that throughout their empire, Japanese authorities built public health and medical infrastructure and enacted various related disease prevention and health policies (e.g., hospitals, medical schools, research institutions, hygiene education and sanitary reform, vaccination campaigns), particularly in Taiwan - its 'model colony' - and in Korea and Manchuria. ${ }^{6}$ As discussed by Michael Shiyung Liu, the purpose of these policies was, as in other empires, first and foremost to protect the Japanese population from local diseases, leading to a greater focus on urban areas. With time, the health of the colonised population also became a concern, and the colonial regime increasingly saw medicine and public health as a means to promote 'civilisation'. Colonies also provided an opportunity for Japanese doctors and scientists to escape academic hierarchies and restrictions in Japan through their research of colonial medicine. ${ }^{7}$ In each place, the colonial government used Japanese civilians, colonial administrators and designated police forces and cultivated local medical personnel by creating education and training programs. The main purpose of military medicine, on the other hand, was to provide health care to soldiers. In Taiwan, for example, while the Japanese military initially played

\footnotetext{
${ }^{3}$ The war between Japan and China has various names, which reflect the controversial nature of its historical memory. In Japanese, it is called the Japan-China War (Nicchū sensō 日中戦争). In English, it is usually called the Second Sino-Japanese War and in Chinese, it is typically called the War of Resistance against Japan (Zhōngguó Kàngrì Zhànzhēng 中国抗日战爭) and related variations, which are often used by China scholars as well. I chose the War in China, since it is a relatively simple and neutral term in comparison to the others; it does not conflate the war with the so-called 'First' Sino-Japanese War of 1894-5, and it emphasises the Japanese perspective, on which the article focuses.

${ }^{4}$ On the origins of the war, see Mark Peattie, 'The Dragon's Seed', in Edward Drea, Mark Peattie and Hans van de Ven (eds), The Battle for China (Stanford: Stanford University Press, 2011), 48-78, particularly, 75-8.

${ }^{5}$ It should be noted that Japan's intervention in Chinese affairs as an imperial power had already begun in the late nineteenth century, in what Peter Duus refers to as the 'informal empire'. Nonetheless, as he notes, this intervention was unstable and limited in scope. See Peter Duus, 'Japan's Informal Empire in China, 1895-1937: An Overview', in Peter Duus, Ramon H. Myers and Mark R. Peattie (eds), The Japanese Informal Empire in China, 1895-1937 (Princeton: Princeton University Press, 1989), xi-xxix.

${ }^{6}$ Colonial policies, their effects and repercussions, changed according to time and place. See, for example: Tod Henry, Assimilating Seoul (Berkeley: University of California Press, 2014), 130-67; Iijima Wataru, Malaria to teikoku (Tokyo: Tokyo daigaku shuppankai, 2005); Iijima Wataru and Wakimura Kōhei, 'Kindai ajia ni okeru teikokushugi to iryō kōshū eisei', in Miichi Masatoshi, Saitō Osamu and Wakimura Kōhei (eds), Shippei kaihatsu teikoku iryō: ajia ni okeru byōki to iryō no rekishigaku (Tokyo: Tokyo daigaku shuppankai, 2001), 75-104; Jeong-ran Kim, 'Malaria and Colonialism in Korea', Social History of Medicine, 29, 2 (2016), 360-83; Miriam Kingsberg, Moral Nation: Modern Japan and Narcotics in Global History (Berkeley: University of California Press, 2014); Michael Shiyung Liu, Prescribing Colonization: the Role of Medical Practices and Policies in Japan-Ruled Taiwan (Ann Arbor: Association for Asian Studies, 2009); Ming-Cheng M. Lo, Doctors within Borders (Berkeley: University of California Press, 2002); Ruth Rogaski, Hygienic Modernity (Berkeley: University of California Press, 2004), particularly 254-84.

${ }^{7}$ Liu, op. cit. (note 6), 56, 65, 73-4, 79-82, 132, 167. On the effect of similar academic restraints on research and the opportunities for scientific freedom in the empire, see also Kingsberg, op. cit. (note 6), 142-3.
} 
a role in colonial disease prevention as a means of protecting the troops, it was soon replaced by the colonial civil administration. ${ }^{8}$

Though some patterns and structures recurred, the situation in occupied China was quite different. Rather than following the practice established in Taiwan and Korea of creating a local body of health care providers and knowledge producers, Japan's tentative military grasp and the nature of the occupation placed the military at the center of health policies. ${ }^{9}$ According to Iijima Wataru, the military mobilised numerous researchers and physicians to establish public health, research and medical facilities. ${ }^{10}$ Japanese civilian organisations, especially the Dōjinkai 同仁会 (Universal Benevolence Organisation) ${ }^{11}$, cooperated with the military as well. The Dojinkai was established in 1902 by a group of civilians to promote medicine and public health in China and Asia. ${ }^{12}$ Starting in 1937, the Japanese military assumed supervision and control of the Dōjinkai, and its existing hospitals in China now served military purposes. It also sent medical teams to the countryside. ${ }^{13}$ Besides supervising and initiating medical activities, in the Chinese countryside, the Japanese military interacted directly with the rural population. This article focuses on largely unexplored medical encounters that resulted from this interaction, in order to examine the routines and relationships brought about by the occupation, and the role that trust played in these encounters. $^{14}$

The article's historical intervention is thus threefold. First of all, it positions the military at the center of discourse on imperial medicine, which often focuses on colonial administrators, the state and civilian institutions. David Arnold, for instance, in his discussion of the British army's role in the development of colonial medicine in India during the nineteenth and early twentieth centuries, notes overlaps between military and non-military spheres. Yet Arnold stresses that, by and large, the British army was a medical enclave. Medical policies were designed and implemented by colonial authorities - not by the army. ${ }^{15}$ So was generally the case in the Japanese empire, as noted above. ${ }^{16}$ In China, however, occupation and war gave the military a more central role that requires exploration.

This is the article's second point of intervention - highlighting the unique medical power relations that developed under military occupation, which were related to, yet different from, the power relations in imperial medicine and which are often overlooked in historical research. ${ }^{17}$ Improving and maintaining the health of the local population was not the Japanese military's top priority in China. As noted, the role of military medicine, as in other militaries then and now, was first and foremost to protect the health of soldiers. The health of local populations was important primarily to prevent diseases from spreading

\footnotetext{
${ }^{8}$ Rogaski, op. cit. (note 6), 257-9.

${ }^{9}$ Ibid., 260-1. The Dōjinkai intended to build programs for medical education in China before the war but did not succeed. Its hospitals were located in major cities. Lo, op. cit. (note 6), 155-7.

${ }^{10}$ Iijima, op. cit. (note 6), 189.

${ }^{11}$ Translation following Lo, op cit. (note 6), 153.

${ }^{12}$ Lo, op. cit. (note 6), 153-5, 156. According to Ding Lei, two major factors inspired the establishment of the Dōjinkai:
} (1) Western missionary activities in China, which employed Western medicine and (2) Japan's development into a modernisation model following the Sino-Japanese War of 1894-5 and a destination for Chinese students to study science and medicine. See Ding Lei, 'Kindai nihon no taichū iryō bunka katsudō: dōjinkai kenkyū (1)', Nihon ishigaku zasshi, 45, 4 (1999), 546-9.

${ }^{13}$ Iijima, op. cit. (note 6), 193-4; Lo, op. cit. (note 6), 156-7.

${ }^{14}$ See Nicole Barnes's groundbreaking discussion of war as the creator of relationships and of care as the facilitator of intimacy: Nicole Barnes, Intimate Communities: Wartime Healthcare and the Birth of Modern China, 1937-1945 (Berkeley: University of California Press, 2018).

${ }^{15}$ David Arnold, Colonizing the Body (Berkeley: University of California Press, 1993), particularly 61-102.

${ }^{16}$ Liu writes that, in the early years of Japan's occupation of Taiwan, the Japanese colonial government established militarystyled medical facilities that treated the local population, but this did not become the rule. Moreover, he notes that there was largely a disconnect between the military's health conditions and those of Taiwanese society. Liu, op. cit. (note 6), 8, 60.

${ }^{17}$ Contemporary ethnographic research reveals uncannily similar stories of military medical professionals interacting with local populations in the midst of war and occupation, interactions full of tension, paradoxes and dilemmas on the one hand and humanitarianism on the other. See: Stuart Gordon, 'The British Military Medical Services and Contested Humanitarianism', in Sharon Abramowitz and Catherine Panter-Brick (eds), Medical Humanitarianism: Ethnographies of Practice (Philadelphia: University of Pennsylvania Press, 2015), 176-90. 
to the occupying military forces. ${ }^{18}$ This article presents another perspective, arguing that in some cases, medicine went beyond curing and preventing disease. It became a site of encounter and intimate interaction between Japanese soldiers and local people and even served as a tool for mobilising local support, crucial for maintaining the unstable occupation.

This leads to the article's final point of intervention - the nature of the history of medicine during the War in China. A number of exciting works have been published over the past few years on the history of medicine among the Chinese Communist and Nationalist forces and the population under their control. ${ }^{19}$ When it comes to the Japanese military during the war, research has largely focused on war crimes, particularly the medical atrocities committed by the notorious Unit 731, the crumbling of medical ethics and the implications of biological and chemical warfare ${ }^{20}$ The importance of these topics in world history cannot be overstated, yet they tell only part of the story. This trend has recently started to change. Lee Pennington's seminal work on the history of wounded and disabled Japanese soldiers includes an analysis of how the War in China helped to change the ways in which the Japanese Imperial Army dealt with casualties. Nakamura Eri's pivotal research on trauma and post-traumatic stress in the Japanese military analyses the impact of the War in China on soldiers' experiences and on how the state and military medicine dealt with the afflicted. ${ }^{21}$ This article adds to these works by revealing another aspect of the war and its impact on the body and on medical relationships. By providing a glimpse of the occupation's mundane nature through the history of medical care, the article draws a subtler picture of the past.

To do so, the article focuses on the testimonies of two groups of men who served on the ground medics and pacification agents. They were not doctors or military decision-makers but rather ad hoc care providers. Eiseihei 衛生兵 (medics or aidmen) were soldiers who became medical care providers, not by their own choice but by the army's. ${ }^{22}$ Unlike physicians, they were common soldiers in whom the army decided to invest time and resources to train in basic medical topics. Japanese military medical personnel included military physicians, pharmacists, medics, stretcher bearers, medical engineers, military veterinarians and eventually also female nurses. ${ }^{23}$ Medics and stretcher bearers were the most numerous. This was no accident. Medics were intended to compensate for the limited availability of military doctors by delegating care to the hands of more quickly trained laymen. ${ }^{24}$ Medics' responsibilities and sites of

\footnotetext{
${ }^{18}$ Arnold, op. cit. (note 15), 96-7.

${ }^{19}$ Barnes, op. cit. (note 14); Wayne Soon, 'Blood, Soy Milk, and Vitality: the Wartime Origins of Blood Banking in China, 1943-45’, Bulletin of the History of Medicine, 90, 3 (2016), 424-54; John R. Watt, Saving Lives in Wartime China (Leiden: Brill, 2014).

${ }^{20}$ Numerous works have been published on Unit 731. A few examples: Nanyan Guo et al. (eds), Japan's Wartime Medical Atrocities: Comparative Inquiries in Science, History, and Ethics (London: Routledge, 2010); Sheldon H. Harris, Factories of Death: Japanese Biological Warfare in 1932-45 and the American Cover-up (London: Routledge, 1994); Nanasan'ichi kenkyūkai (ed.), Saikinsen butai (Tokyo: Banseisha, 1996); Tsuneishi Keiichi, Nanasan'ichi butai (Tokyo: Kōdansha, 1995).

${ }^{21}$ Lee Pennington, Casualties of History: Wounded Japanese Servicemen and the Second World War (Ithaca: Cornell University Press, 2015), particularly 137-62; Nakamura Eri, Sensō to torauma (Tokyo: Yoshikawa kōbunkan, 2018).

${ }^{22}$ The English word medic typically refers to doctors and other medical personnel. In the context of military medicine, however, it usually refers specifically to soldiers who were not doctors, but whom the military trained and used as medical care providers, particularly in the unit setting. In the Japanese case, medics also served in military hospitals as medical orderlies, but the same term was used for both. Moreover, in certain periods, one soldier could serve in both settings during his military service. Medics also served in the Japanese navy, but the article focuses predominantly on the army. Eiseihei 衛生兵 was the official term for army medic in 1937. For more, see Reut Harari, 'Medicalised Battlefields: the Evolution of Military Medical Care and the "Medic" in Japan', Social History of Medicine, https://doi.org/10.1093/shm/hkz042 (1 June 2019).

${ }^{23}$ Until 1919, women nurses supported the military through external organisations. Most important of these was the Japanese Red Cross, which increasingly came under the military's authority as a sub-organisation. From 1919, women nurses were employed by the military, and starting in 1944, they were trained by the military itself. Konoe Tadateru, 'Senjō no sekijūji kangofutachi', in Jūgun-kangofutachi no daitōa sensō kankō iinkai (ed.), Jūgun-kangofutachi no daitōa sensō (Tokyo: Shōdensha, 2006), 8-9.

${ }^{24}$ For the early history of medics and stretcher bearers, see Suzuki Noriko's pathbreaking research, such as 'Eiseitai hensei ni muketa rikugun kango seido no dainiji kaikaku' Kokushikan shigaku, 14 (2010), 85-104; 'Rikugun no eisei yōin hojū seido no seiritsu katei', Gunji shigaku, 46, 2 (2010), 111-26. See also Harari, op. cit. (note 22).
} 
service changed, but by the time of the War in China, the military largely divided medics between military hospitals and units. ${ }^{25}$ Unit medics moved with their units into the Chinese countryside and came into contact with local populations. Military doctors did as well, as we shall see, but by virtue of the larger number of medics, their participation in missions that doctors did not usually join and the focus of their role on the provision of care, medics interacted more frequently with rural populations than did other military medical personnel. By focusing on this group, the article also gives a voice to these largely forgotten servicemen. The few works hitherto published on the history of medics limit their focus to the position's early development during the Meiji era and to their role as military rather than imperial care providers. $^{26}$

While the medic's role centered on providing medical care to fellow soldiers, pacification agents, senbukan 宣撫官, were part of a wide framework that served a different purpose. Pacification agents accompanied the Japanese military in the Chinese countryside to calm the local population and gain its trust following violent military campaigns. Medicine was one component of their varied efforts to replace fear with trust (usually shinrai 信頼, occasionally shinyo 信用). Timothy Brook has written a seminal work on the history of pacification works, which this article builds upon in many ways. However, Brook focuses largely on the works' political aspect. The medical aspect has largely eluded scholarly attention. ${ }^{27}$

By analysing these encounters and their dynamics, the article reveals a different side of Japan's occupation of China and the unique role medicine and trust came to play in the field. The article is divided into three parts. The first part explores the relationship between medics and soldiers within the army unit, arguing that the Japanese army recognised trust as a fundamental component of the encounter between the caregiver and patient. The second and main part of the article analyses campaigns in which the military mobilised this trust between the care provider and patient to pacify the local Chinese population and to transfer medical trust to the military at large. The third part investigates unplanned medical encounters between medics and members of the local Chinese population. It reveals the humanity that existed in relationships between individuals within the wider context of war, on the one hand, and on the other, argues for the inseparability of trust from fear and violence.

\section{Methodological notes}

The limits of this article should be stressed in advance. First, it relies on testimonies of Japanese military and military-affiliated personnel found in memoirs and oral history interviews, many of them conducted by the author, as well as on military documents. While no historical document is objective, testimonies are by nature subjective. Some of the stories were related orally or in writing decades after the fact. For many years, veterans did not discuss their wartime experiences, and now their numbers are sadly dwindling. To ensure accuracy, I used interviews conducted by other oral history projects with the same interviewees to complement my own whenever possible. Every person is a boundless archive and thus conducting interviews allowed me to discover details that had not come up in other interviews, verify unclear points and ask particular questions pertinent to my research, though most of the stories analysed in the article came up unprompted. Since medics in particular have been researched very rarely, documents and memoirs are scattered in a variety of archives, shops and private hands. The limited number of sources I have been able to unearth makes it difficult to state with any certainty how prevalent

\footnotetext{
${ }^{25}$ The division followed a 1909 reform: Naikaku, 'Rikugun hojū jōrei-chū kaisei', article no. 141, 15 April 1909, Japan Center for Asian Historical Records (https://www.jacar.go.jp, hereafter JACAR) reference: A03020796900.

${ }^{26}$ See works listed in note 24 and Kurosawa Yoshiyuki, 'Rikugun kanbyōnin no kyōiku ni tsuite', Nihon ishigaku zasshi, 38, 2 (1992), 314-5; 'Meiji-ki no rikugun kango shisutemu,' Nihon ishigaku zasshi, 39, 4 (1993), 523-42. Historical research has largely overlooked the history of medics. Medics are usually mentioned in passing and in relation to other historical protagonists. The only published research that places medics center stage beyond Japan is Tracy Shilcutt, Infantry Combat Medics in Europe, 1944-45 (New York: Palgrave Macmillan, 2013), which focuses on the U.S. army.

${ }^{27}$ Timothy Brook, Collaboration: Japanese Agents and Local Elites in Wartime China (Cambridge: Harvard University Press, 2005).
} 
the medical encounters described in the article were. Nevertheless, they reveal information otherwise unavailable, shedding new light on history, albeit partial and subjective.

Second, as it is based on Japanese sources, the article presents the voice of the occupier and not of the occupied. It is possible to imagine through careful reading, and in conjunction with what we know of the war, what the occupied might have thought, but it remains a mere surmise. I hope that future work will retrieve the lost experiences of the local Chinese population to create a more complete and balanced narrative.

Following convention, and unless otherwise written by the original author, Japanese names appear in the article in the Japanese order - last name followed by first name.

\section{Trust and the medic-soldier relationship}

In 1888, Surgeon General Hashimoto Tsunatsune recognised the need to strengthen the medic's connection to his unit. The surgeon general was the head of the army's top medical authority, the Military Medical Department. Medics served in the Meiji army from the beginning of general conscription in 1873, with even earlier antecedents. But medic service changed over time, as did its purpose, training, the space in which medics served and the name of the role. ${ }^{28}$ Before the 1888 reform, medics underwent basic infantry training, irrespective of the unit to which they were assigned. ${ }^{29}$ To reinforce the medic's position in the unit, Hashimoto decreed that all unit soldiers (infantry, cavalry, artillery, engineering, logistics, respectively) would undergo basic army training together and only then would the company's commanding officer select soldiers - literate, inclined to learning, and possessed of a temperament suitable for caregiving - to undergo additional medical training. ${ }^{30}$ After completing the medical course, the soldiers would return to their units as medics. ${ }^{31}$ Thus, Hashimoto enabled a closer connection between the medic and his patients, binding them together through shared experiences.

However, placing them at an equal footing could also complicate the medic-patient relationship, since it could harm the medic's authority among his fellow unit soldiers. Consequently, Hashimoto added another provision to the reform, granting unit medics a higher military rank than other soldiers in their unit:

The skills and capacity of medics are equal in level to the learning obtained by first class privates. More than that, from the perspective of their medical professional duties, if they were not placed at a higher rank than that of the common soldier, [it could affect] the trust [shinyō 信用] the patient [would have for the medic] in a significant way. Therefore, hereafter [medics] will be placed at the same rank as privates first class. ${ }^{32}$

Medics lacked the professional credentials of military doctors. To possibly compensate for this, Hashimoto suggested prolonging medical training to 6 months. ${ }^{33}$ Higher military rank would demonstrate the medic's skills and knowledge. More important, rank would cultivate 'trust' among soldiers towards medics, even though they had undergone basic training as equals. Thus, hierarchy would supplement training as the source of the medic's medical authority.

\footnotetext{
${ }^{28}$ Harari, op. cit. (note 22); Rikugun gun'idan (ed.), Rikugun eisei seido-shi (Tokyo: Kodera Akira, 1913), 324-49.

${ }^{29}$ Ōyama Iwao, 'Kangosotsu kyōiku kisoku', 28 December 1887, JACAR reference: C09050160000.

${ }^{30}$ Naikaku, 'Rikugun eiseibu gen'eki kangoshu hojū jōrei', 24 December 1888, JACAR reference: A03020028200.

${ }^{31}$ Between 1923 and 1933, the army selected men to serve as medics already during their conscription exam. However, apart from that decade, the abovementioned criteria for medic selection remained in place and followed basic training all the way through 1945. The one exception was hospital medics, who again were selected during the conscription exam starting in 1937. See Rikujō jieitai eisei gakkō shūshinkai (ed.), Rikugun eisei seido-shi, Shōwa-hen (Tokyo: Hara-shobō, 1990), 359-61.

${ }^{32}$ This quote is taken from Hashimoto's suggestion for the reform, issued in November 1888. Cited and transcribed in Suzuki, 'Eiseitai hensei', op. cit. (note 24), 96.

${ }^{33}$ Ibid. 93.
} 
With authority, however, also came responsibility. A textbook from 1915 addressed the potential clash between violence and trust within the medic-patient power relationship:

The main purpose of the medic role is to treat patients with affection and in good faith. [Medics] should speak and act carefully, never violently or cruelly, never thoughtlessly or frivolously...In this way, [the medic] can gain the trust of the patient, and begin to succeed in [his] caregiving work. ${ }^{34}$

The above quote, which appears in earlier textbooks as well, suggests that violence could be displayed by medics. This was particularly the case during the Meiji era (1868-1912) as new forms of care and norms of behavior for the medical encounter developed in both military and civilian contexts. Evidence from the Boshin War (1868-9), which opened the Meiji era, indicates that soldiers behaved violently towards their caregivers as well. ${ }^{35}$ The textbook's stipulation may have resulted from these experiences, suggesting that violence could hinder the cultivation of mutual 'trust' and respect, so fundamental to medic service.

Hashimoto's suggestion may have also reflected his understanding of the problematic position medicine held within the military framework more broadly. Medics saved lives, but they were an anomaly in an environment that used violence as its tool. For instance, in the introduction to a medic textbook published after the 1888 reform, one finds the following justification for the medic role:

Army caregivers [kangonin 看護人] must bountifully possess courage and an obedient spirit. As military men in particular, caregivers have to be first and foremost courageous, since they must avoid various unpleasant [situations], while tending [the sick and wounded]. Moreover, they must brave danger, while not considering their own life, treating infectious diseases and providing emergency care to the wounded in the midst of artillery smoke and a rain of bullets. Furthermore, they must bountifully possess an obedient spirit, to serve while following the orders of superior officers, as even the smallest transgression will not be excused... Upon passing their military training the non-commissioned medic officer, the pharmacist and medic, acquire specialised learning and then enter military service as everyone else. Accordingly, the honor obtained from taking up a weapon and directly targeting the enemy is one and the same [as military medical care] [emphasis added]. ${ }^{36}$

The textbook's insistence that medical care is as honorable as active fighting suggests that this equality was not taken for granted. Indeed, this justification recurred in medic textbooks all the way through 1941, indicating that there continued to be a perceived gap between medicine and combat. ${ }^{37}$ It also demonstrates that the Japanese army, as an institution, recognised the importance of medicine.

Medics - and the element of trust - became increasingly important with the militarisation of the 1930s and 1940s. Even before then, medics placed their lives at risk by working near battlegrounds and by exposing themselves to infectious disease. Generally speaking, unit medics went out to the field with their units, provided first aid when needed in battle and on the march, prevented and provided care for diseases that spread among the ranks and maintained the health of the troops, while hospital medics assisted military doctors in surgery, provided post-operative care, and tended to the sick. ${ }^{38}$ However,

\footnotetext{
${ }^{34}$ Rikugun Imukyoku, Kango kyōtei (Tokyo: Kobayashi Matashichi, 1915), 3.

${ }^{35}$ Suzuki Noriko, 'Rikugun ni okeru kangosotsu kyōiku no hajimari', Nihon kango rekishi gakkai-shi, 23 (2010), 94.

${ }^{36}$ Rikugun Imukyoku, Rikugun kangogaku shūgyōhei kyōkasho (Tokyo: Kobayashi Matashichi, 1890), 1-2.

${ }^{37}$ Rikugun Imukyoku, op. cit. (note 34), 1-4; Rikugunshō Imukyoku, Kangosotsu kyōtei sōan (Kyoto: Wada Buyōsha, 1924), 1-2; Yamada Hirotomo, Kangohei kyōtei (Publisher unknown, 1931, original from 1928), 1-3; Yamada Hirotomo, Eiseihei kyōtei (Tokyo: Buyōdō, 1932, based on version from 1928), 1-3; Eiseihei suchi, issued by Fujitani Yoshisaburō (Tokyo: heisho shuppansha, 1941), 388-90.

${ }^{38}$ Medic service was largely divided between army units and - before 1888 and again from 1909 - army hospitals of different kinds. Rikugun gun'idan (ed.), op. cit. (note 28), 324-5. The earliest official pronouncements of medic duties were from 1875 and 1876. Yamagata Aritomo, 'Kanbyōnin kanbyōsotsu fukumu gaisoku', 10 November 1875, JACAR reference: C08070047300; Rikugunshō, 'Kanbyōnin kanbyōsotsu fukumu gaisoku daigo-shō zōka', 16 December 1876, JACAR reference: C08070815700. Later pronouncements from before and during the War in China can be found in medic textbooks, such as Yamada, Eiseihei kyōtei, op. cit. (note 37); Kangochō kyōtei sōan, issued by Kuriki Chōshichi (Tokyo: Hifumikan, 1938).
} 
during the 1930s and 1940s, the nature of the battlefield and 'the line' changed. New weapons such as aerial bombardment made any place a potential battlefield. ${ }^{39}$ At the same time, as we shall see, the Japanese army participated in numerous small-scale operations in which medics advanced alongside combat soldiers, serving as the sole caregivers. Modern warfare thus placed medics in the line of fire more than ever before.

As medics moved deeper into the battlefield, unit soldiers became even more dependent upon them. For instance, cavalry unit medic Ikeda Tadashi related that, when he began medical training in 1940, one of the first things the instructor taught him and the other trainees was the importance of their own lives, given the dependence of others upon them:

Your goal as medics is to provide care to the wounded. Your job is to allow those who are lightly wounded to pick up a rifle again and fight, and to send those who are gravely wounded to the hospital. That is why you are not to take up a weapon yourselves. It is because you are not allowed to die in battle. If you were to die in battle, the main force - the combatant soldiers - would not go out [and fight]. It is because there are men in the back to rescue them that they move forward. ${ }^{40}$

International agreements protected military medical personnel, but on condition that they do not fight and that they carry weapons only to defend themselves or their patients. ${ }^{41}$ This immunity was imperative, according to Ikeda, because the entire battle relied on the presence of medical personnel. They were the ones who made it possible for combatants to risk their lives. Physicians were also indispensable of course, but medics were both more numerous and more vulnerable, since officially, physicians were to remain behind the line of fire. ${ }^{42}$

Under these conditions, the trust Surgeon General Hashimoto wished to foster between soldiers and medics in 1888 became even more imperative. And yet, in the culture of total war, soldiers also interpreted medics' non-combatant role as a weakness. For instance, according to former medic Ikeda, on the battlefield, in the most life-threatening situations, soldiers referred to him in respectful terms, such as 'Mr. Medic' (eiseihei-san 衛生兵さん) or Mr. Ikeda. However, beyond the battlefield, soldiers in his unit often called him by a trivialising nickname - yo-chin (iodine). ${ }^{43}$

Iodine came to be associated specifically with unit medics, since they would often apply iodine as an antiseptic to treat wounds. This association generally had positive connotations. As former medic Yoshida Takashi explained:

A medic would always carry iodine, yodochinki, as part of his daily medical supplies. When an infantry soldier would get injured in action etc., [the medic] would immediately apply iodine to the opening of the wound to disinfect the bacteria and cure it. When it touches the opening of the wound it is very painful and because of that, it is the most hated. But on the other hand, [the wound] is quick to heal, and so for a medic [iodine] is invaluable. That is why [medics] were called by infantry soldiers etc. yo-chin as a shortened term of endearment. ${ }^{44}$

\footnotetext{
${ }^{39}$ See Sheldon Garon, 'On the Transnational Destruction of Cities: What Japan and the United States Learned from the Bombing of Britain and Germany in the Second World War', Past and Present, 247 (2020), 235-71.

${ }^{40}$ Ikeda Tadashi, Taizuki esieihei (Tokyo: Kindai bungeisha, 1990), 5-6.

${ }^{41}$ 'Convention for the amelioration of the condition of the wounded in armies in the field. Signed at Geneva, 22 August 1864', articles 1-2, in Dietrich Schindler and Jiri Toman (eds), The Laws of Armed Conflicts (Leiden: Martinus Nijhoff Publishers, 2004), 366; 'Convention for the amelioration of the condition of the wounded and sick in armies in the field. Signed at Geneva, 6 July 1906', articles 7-8, in Schindler and Toman, 388.

${ }^{42}$ Aerial bombings and other conditions changed this stipulation in reality, placing physicians in greater danger as well. See, for instance, Karube Shigenori, 'Inpa-lu: aru jūgun'i no shuki' (Tokyo: Gendaishi shuppankai, 1979), particularly 37-8.

${ }^{43}$ Ikeda, op. cit. (note 40), 6.

${ }^{44}$ Letter correspondence with the author, 3 November 2013. Yoshida served as an army unit medic from 1943 until the end of the war. He spent most of his service in New Guinea.
} 
Painful yet invaluable. Nonetheless, the nickname yo-chin also had a diminishing connotation, as Ikeda noted, because it implied that medics could not do anything beyond smearing iodine. ${ }^{45}$ Moreover, the association of medics with this substance emphasised their non-combatant role. Former medic Mutō Masatoshi similarly distinguished between the medics' image and their importance on the battlefield:

...everyone would make fun of medics...by calling them yo-chin, yo-chin. Such people were soldiers who had never been to war. Once they went to the front, they would see how much work medics actually did. A unit-attached medic moves with the unit. The unit performs under fire. So, there was a trench, a hole that is dug in the ground, in which everybody went.... When it's targeted, the medic can't stay in the back... [the medic] has to provide treatment in the midst of flying bullets... That is why many die... when I became a medic, I thought that medics were the ones who stayed in the back, treating the injured. Not a bad role at all, I thought. Far from it. ${ }^{46}$

Thus, the medic's association with medicine - and his higher rank - did not always foster the trust and respect hoped for in 1888. But in battle, the importance of medics and the great risk in which they were placed became evident. It was the violence of war that strengthened the trust soldiers bestowed upon medics.

This fluctuation between trust and trivialisation persisted during the War in China, since the army was not continuously engaged in warfare. On the contrary, one of the characteristics of the war was intense moments of fighting and violence punctuating lulls in military activity. During these lulls, medics dealt with the fundamental tensions within their role. It was in China, however, that trust gained a new significance. As medics encountered a group of patients they were not trained to treat, they discovered that military rank did not always foster trust but could rather obstruct it.

\section{Planned encounters: medical pacification}

\section{Medics in the Chinese countryside}

Imazu Shigeru was enlisted to the Japanese army in 1942. Immediately after, he was sent to China where he underwent basic training. While stationed in Beijing, he and one other soldier were selected from among 200 soldiers in his company to undergo additional medical training. Between 1943 and 1945, he served as a unit medic in an infantry battalion in northern China and participated as medic in a number of battles. In April 1945, he transferred to a Special Guards battalion, where he served until the end of the war a few months later. ${ }^{47}$ As a unit medic in China, Imazu engaged in various activities:

[I]n a unit there was about one military physician...When fighting got rough, this was insufficient. The one military physician of the unit was not always there. In such a case the non-commissioned medic officers would replace him, and in certain times and circumstances would have to conduct simple surgeries...

So you treated injuries, battle wounds, diseases in the base clinic, etc.?

All of that.... [I also accompanied] detachment forces. A detachment was a small force of about ten, twenty soldiers from within the unit, sent to an important location. You couldn't deploy a doctor with them. So, in such cases, an experienced medic, a non-commissioned medic officer, etc., would go with the detachment and provide treatment. We [the detachment force] would also conduct pacification works (senbu kōsaku 宣撫工作) because it was imperative to maintain the peace in the

\footnotetext{
${ }^{45}$ See also Seki Ryō, Gun'i-san yomoyama monogatari (Tokyo: Kōjinsha, 1998), 80.

${ }^{46}$ Author interview with Mutō Masatoshi, 14 June 2014. Mutō served as an army unit medic and later army hospital medic from 1943 until the end of the war. He spent his service stationed in Kyushu, Japan.

${ }^{47}$ The analysis of Imazu's service is based on an interview conducted by the author on 16 December 2013, and an interview conducted by the Japan Veterans Video Archive Project, Senjō taiken hōei hozon no kai, 戦場体験放映保存の会, on 3 November 2012. The association kindly shared its interview record with the author.
} 
area where the unit was stationed. So there was medicine called 'pacification medicine' (senbuyaku 宣撫薬) for the Chinese common people, apart from the medicine used by soldiers. Generally speaking, [it included] medicine for stomachaches, ${ }^{48}$ [medicine] to put on wounds such as iodine, etc.... ${ }^{49}$

The circumstances of war and the scarcity of military physicians placed great responsibility on Imazu's shoulders. As a sole care provider in the Chinese countryside, he was responsible not only for the health of the detachment force soldiers but also, indirectly, for the security of the entire unit: by providing care to the local population, he was to calm the bleeding Chinese countryside. The advance of the Japanese military into China was accompanied by great violence. Apart from large battles, the army raided villages and created encampments as it moved, resulting in destruction and mass fleeing of the local population. However, to build a solid occupation, prevent the population from assisting the Chinese resistance armies and rule without relying on force alone, the military wished to gain cooperation on the ground. Medicine proved to be a useful tool in gaining the hearts of the people in an environment rife with fear, violence and devastation.

The Japanese army created the medic role for the purpose of treating soldiers. Accordingly, medic training focused on the young male body and on methods of emergency care, such as cleaning and bandaging wounds, treating fractures and stopping bleeding. Training also included methods for detecting and preventing diseases to which soldiers were prone in the context of military life and in the distinct epidemiological environments of the Japanese empire. ${ }^{50}$ Treating civilians of all ages and genders, from a different cultural background, who spoke a different language, was not part of medic training, but it became part of the role of medics in northern China. The result was a unique form of interaction between the military and members of the Chinese population through the mobilisation of medical trust.

According to Imazu, because these missions were dangerous, military doctors usually did not accompany them, only medics. ${ }^{51}$ There is evidence to the contrary, as demonstrated below, but it is plausible that, as Imazu described, these cases were not the rule. Within this tense atmosphere, the humane aspects of medicine allowed Imazu to overcome his patients' fear:

No other soldier could become as close with the people. Medics saved lives...In that area there was no doctor, which made life uneasy. A doctor takes a look at any disease, terrible diseases as well, whatever there is. And because he is a doctor, he gains trust and respect... Such detachment forces went among the people to preserve public order etc. Although it changed according to case, it was a unique situation, which provided many opportunities to gain trust. And if you were not trusted, it could become dangerous - not very, but still... [emphasis added]. ${ }^{52}$

According to Imazu, for the local population, medics were doctors for all intents and purposes. The areas to which the Japanese military arrived usually had little access to medical care. Before the war began, the Nationalist government had made efforts to build a system of rural health care. However, these efforts

\footnotetext{
${ }^{48}$ Later in the interview, Imazu mentioned seirogan (formerly 征露丸, currently 正露丸) as one of these medicines. Seirogan has an interesting history of its own, tied to war, empire and military action. According to Hoi-Eun Kim, the Japanese army developed and used it from the early twentieth century, particularly during the Russo-Japanese War, to deal with gastrointestinal problems. Pharmaceutical companies quickly promoted it commercially to the public as well, using militaristic and imperialistic slogans, tying together political and commercial interests. Military use of the pill continued through several wars, and the medication is still widely sold in Japan, though stripped of its original imperialistic meanings. See Hoi-Eun Kim, 'Cure for Empire: The "Conquer-Russia-Pill”, Pharmaceutical Manufacturers, and the Making of Patriotic Japanese, 1904-45', Medical History, 57, 2 (2013), 249-68.

${ }^{49}$ Author interview with Imazu Shigeru, 16 December 2013.

${ }^{50}$ See, eg., Yamada, Eiseihei kyōtei, op. cit. (note 37), 19-20, 48-49 52-299.

${ }^{51}$ Japan Veterans Video Archive Project, interview with Imazu Shigeru, 3 November 2012.

${ }^{52}$ Author interview with Imazu Shigeru, 16 December 2013.
} 
were limited in scope and largely curtailed by the war. ${ }^{53}$ Thus, many continued to rely on the local community and care providers when available and to subscribe to local medical views of disease and care. ${ }^{54}$ The vulnerability of the sick and wounded, the shortage of alternatives and the inability of the poor to pay helped Japanese medics, who provided care for free, to gain people's trust.

The pacification campaigns aimed to enlist the trust that lay at the foundation of the caregiver-patient relationship and to transfer it from the medical context to the Japanese military at large. Alternatively, the campaigns sought to use the trust Surgeon General Hashimoto wished to cultivate through military rank in 1888 as a tool to break down the obstacles created by military uniform. However, just as the medicsoldier relationship relied on the medic's conduct and on the military's strategic position, in the Chinese countryside, too, the medic's individual personality and the military's state of supplies shaped medical encounters. Medicine in these delicate situations gave medics power that they could wield in different ways. As Imazu noted, 'There were those who abused this, who acted for their own benefit', but 'I did all that I could for the Chinese people, so I had a good reputation'. ${ }^{55}$ The army was aware of this potential for misconduct, as implied in a 1938 report addressing medics in pacification campaigns: 'Based on the experience so far, it is believed that when free treatment is provided zealously, it yields the greatest pacification results ${ }^{56}$ In other words, not everyone was uniformly zealous. Moreover, Imazu noted that the help given to Chinese patients depended on the military's position in the war, not only the medic's goodwill:

At the beginning... it was alright to use the Japanese - that is, the medicine used by the army - as pacification medicine to win over the Chinese population nearby, although the medicines were originally separate. But then, towards the end of the war, there was no room for such leisurely [behaviour]. Even medicine for military use was insufficient. ${ }^{57}$

While all was going well, medics would occasionally provide the local population with medicine designated for soldiers when it was needed. Yet, when supplies ran short towards the end of the war, the army received precedence. Military action came before imperial control and pacification medicine lost its meaning.

Perhaps, the most important factor influencing the pacification medical encounter was the memory of violence. Within the army unit, the violence of warfare strengthened the trust bestowed upon medics by their comrades who depended on them more than ever. But the local population's experience of violence made it more difficult for medics to create stable, friendly bonds and to instill a sense of trust in the Japanese military beyond the medical encounter.

\section{Pacification agents as caregivers}

The use of medicine to pacify the Chinese population was part of a broader initiative to cultivate trust in order to solidify the Japanese occupation. Pacification campaigns originated in Manchuria following the establishment of Manchukuo in 1931 and spread to China in 1937. The South Manchurian Railway Company (Minami manshū tetsudō 南満州鉄道, Mantestu 満鉄 for short), created 'pacification squads' (senbuhan 宣撫班), consisting of men who were familiar with local languages and culture.

\footnotetext{
${ }^{53}$ Nicole Barnes and John Watt show that the Nationalist government continued and initiated various healthcare reforms in territories unoccupied by the Japanese military. See Nicole Elizabeth Barnes and John R. Watt, 'The Influence of War on China's Modern Health Systems', in Bridie Andrews and Mary Brown Bullock (eds), Medical Transitions in Twentieth Century China (Bloomington: Indiana University Press, 2014), particularly 227, 230.

${ }^{54}$ See, eg., Henrietta Harrison, 'The Experience of Illness in Early Twentieth-century Rural Shanxi', East Asian Science, Technology, and Medicine, 42 (2015), 39-71.

${ }^{55}$ Author interview with Imazu Shigeru, 16 December 2013.

${ }^{56}$ Umezu butaichō, 'Kōdō ni okeru kōsaku', June 1939, JACAR reference: C11110483400.

${ }^{57}$ Author interview with Imazu Shigeru, 16 December 2013.
} 
They included company employees, most of whom were Japanese. The groups were to use their knowledge to blend into the population and to establish local political leadership. ${ }^{58}$ According to the official military history, the man who established these pacification squads in Manchuria, Yaginuma Takeo, was summoned in July 1937 to Tianjin military headquarters to plan a similar pacification project in northern China. ${ }^{59}$ Testimonies reveal that in the 1940s, they spread beyond the north. ${ }^{60}$

Pacification work combined benevolence with political and military pragmatism. It included steps to rehabilitate the Chinese countryside, but its main purpose was self-serving - to gain the trust of the local people and to eliminate their support of the Chinese resistance armies, so that the Japanese military could advance smoothly and build its occupation state. ${ }^{61}$ The military first needed to encourage the many who had fled to return. A navy commander, Koba Keiten, described a campaign to take over a nameless Chinese island in the South Sea. According to Koba, when the forces arrived, about a fourth of the island's 20,000 people had fled. ${ }^{62}$ Koba sought to rehabilitate the area and embolden the people to return by demonstrating what some already recognised - that 'trusting the Japanese military paid off. ${ }^{63}$ Accordingly, he tried to revive the local economy by promoting trade with the mainland (the unit acting as a middleman) and abstaining from collecting taxes. Next he worked to improve people's daily lives, starting with their health and continuing with education, building schools and teaching the Japanese language. ${ }^{64}$ Koba could allegedly see results already after the first initiative:

Chinese people are very suspicious and they don't often bestow their trust (shinyō 信用). But, once they do, they trust thoroughly (shinrai 信頼)...That is why the fact that they were already willing to trust the Japanese military was really something. I was delighted that the first stage of the works succeeded [emphasis added]. ${ }^{65}$

It was not easy to gain this trust because of the relationship between pacification workers and the Japanese military. Like medics, pacification agents held a position that set them apart from other soldiers. For medics, it was the medicine they practiced that differentiated them. Pacification agents were not officially soldiers at all but rather military-affiliated civilians and thus outsiders to a certain extent. ${ }^{66}$ As was the case for medics, this distinction occasionally caused confusion, tension and friction between the agents and the units they accompanied. ${ }^{67}$ At the same time, this distance from the military assisted them in gaining the local population's cooperation, since it removed them from the military actions that had led to popular evacuation and fear in the first place. They usually even walked about the villages in white shirts instead of military uniform. ${ }^{68}$

And yet, although pacification agents often worked independently, remaining in the locality on their own, they also moved together with the military and received its protection. Pacification campaigns were under military command, and a pacification squad was supposed to be attached to each army corps and division. ${ }^{69}$ Moreover, besides conciliating the population, pacification agents were also directed to

\footnotetext{
${ }^{58}$ Brook, op. cit. (note 27), 34-6.

${ }^{59}$ Aoe Shunjirō, Dainihongun senbukan (Tokyo: Fuyō shobō, 1970), 59; Sōmubu bunsho, Senbuhan shōshi, 1937, JACAR reference: C11110458400. Yaginuma was also a lyricist of military war songs, such as Tōhikō 討匪行 and Hokushi sensen no uta 北支戦線の歌.

${ }^{60}$ See, for instance, Koba Keiten, Rikusentai senbuki (Tokyo: Shimizu shobō, 1942, originally published in 1941).

${ }^{61}$ Brook, op. cit. (note 27), ch. 2, particularly 38-40.

${ }^{62}$ Koba, op. cit. (note 60), 77.

${ }^{63}$ Ibid., 94 .

${ }^{64}$ Ibid., 103-14.

${ }^{65}$ Ibid., 105.

${ }^{66}$ Brook, op. cit. (note 27), 35.

${ }^{67}$ For example: Aoe, op. cit. (note. 59), 87, 221-2.

${ }^{68}$ Brook, op. cit. (note 27), 35.

${ }^{69}$ Sōmubu bunsho, Senbuhan shōshi: jogen, 1937, JACAR reference: C11110458300. According to Shimazaki Akemi, this proximity could also create affectionate bonds between pacification agents and their unit, not just friction. Shimazaki Akemi, Senbuhan (Tokyo: Konnichi no mondaisha, 1940), 31-2.
} 
engage in more bluntly strategic actions, such as collecting information of various kinds, which led many people, researchers included, to mistakenly conflate them with the notorious military police, the kenpeitai. ${ }^{70}$ Pacification agents protected communication lines, such as roads and railways that were strategically important to the military, and removed bodies and weapons from former battlefields to make them inhabitable again. They procured food, horses, vehicles, laborers and other necessities for the army. ${ }^{71}$ They engaged in a variety of propaganda tasks. ${ }^{72}$ Most significantly, pacification campaigns followed small but violent military campaigns. ${ }^{73}$ According to one testimony, pacification agents would go out in trucks after military campaigns to bring the locals candy and medicine, tea, salt, etc. ${ }^{74}$ Pacification works thus went hand in hand with the devastation of military actions and, to some extent, facilitated them.

Clearly, medicine was only one aspect of pacification campaigns and in fact occupied a relatively small place. According to a 1937 military report, out of 80 pacification teams only 6 were medical teams (seryōhan 施療班, lit. Free medical treatment teams). ${ }^{75}$ By the end of 1938, only 4 out of 128 teams were medical teams. ${ }^{76}$ When listing the various pacification operations, the report also mentioned medical care in passing, buried among numerous other tasks. Yet despite its relatively small size, reports and testimonies repeatedly argued that medical pacification had the greatest effect in encouraging local cooperation and trust. ${ }^{77}$ Like medics, pacification agents remarked on the scarcity of doctors and the prevalence of disease in the areas they reached. For example, Yamamoto Eiichi, a soldier who served in northern China, described the particular prevalence of skin and eye diseases. According to Yamamoto, there were established medical facilities in the area, but they were too few in comparison to the number of ill people. Moreover, most people could not afford to pay for their services and never saw a doctor. ${ }^{78}$ To them, free care and medication were likely appealing. Medicine became a benevolent weapon, as pacification agent Shimazaki Akemi wrote in 1940:

The people in northern China are hungry, injured and sick. We must help them. If we don't find the most appropriate, the most suitable method of treatment, we will not be able to win a perfect victory...The sick in northern China are currently at a crossroads, deliberating straightforwardly between the Eighth Route Army and the Japanese military. If the enemy administers poison, we should immediately provide an antidote. If the enemy gives out medicine, we have to produce better medicine.... ${ }^{79}$

The success of the Japanese occupation, according to Shimazaki, did not rely only on the results of warfare but also on the competition for the hearts of the people. ${ }^{80}$

What form did pacification medicine take? Military reports do not provide much detail, but testimonies give some insight. It seems the teams circulated among different locations, providing limited

\footnotetext{
${ }^{70}$ Brook, op. cit. (note 27), 36.

${ }^{71}$ Sōmubu bunsho, Senbuhan shōshi: gun ni taisuru kyōryoku, 1939, JACAR reference: C11110459800.

${ }^{72}$ Sōmubu bunsho, Senbuhan shōshi: chūtongun senbuhan daiikki senden keikaku gaiyō, 1937, JACAR reference: C11110458800.

${ }^{73}$ Sōmubu bunsho, Senbuhan shōshi: Sugiyama butai honbu senbuhan - sōsoku, 1939, JACAR reference: C11110461000.

${ }^{74}$ Yamamoto Eiichi, Ai no senbukō (Tokyo: kyōbunkan, 1942), 62.

${ }^{75}$ Sōmubu bunsho, Senbuhan shōshi: honbu tanjō, 1937, JACAR reference: C11110458600.

${ }^{76}$ Sōmubu bunsho, Senbuhan shōshi: joshū kanraku, 1938, JACAR reference: C11110459100.

${ }^{77}$ Aoe, op. cit. (note 59), 187, 290; Sōmubu bunsho, Senbuhan shōshi: Sugiyama butai honbu senbuhan - fuhyō, 1939, JACAR reference: C11110461500, 0188; Tada butai honbu, 'Iryōbu no secchi to sono katsudō', 1940, JACAR reference: C11110462900.

${ }^{78}$ Yamamoto, op. cit. (note 74), 138-9; see a similar example in Brook, op. cit. (note 27), 72-3.

${ }^{79}$ Shimazaki, op. cit. (note 69), 22.

${ }^{80}$ According to Watt, the Nationalist and particularly the Communist leadership tried to curb disease and epidemics and to care for the sick and injured in their respective territories, in order to facilitate resistance to the Japanese military. See Watt, op. cit. (note 19), chs 6-7, particularly 256-8, 274-9. Barnes argues that, through the care they gave the sick and wounded during the war, Chinese nurses bound people together, a unity that was not to be taken for granted at the time and which competed with the efforts Shimazaki described. Barnes, op. cit. (note 14), 88-9.
} 
care and medicine for free. In time, the population grew to recognise the teams and, in some cases, came to them of their own initiative. In other cases, the teams actively searched for the sick and injured. ${ }^{81}$ Like medics, pacification agents were not doctors, but they provided basic care using the medicaments and equipment at their disposal and came to be seen as doctors by some of the locals. ${ }^{82}$ In one case, for instance, the pacification agent wore a white coat, examined people with a stethoscope, checked their chests and stomachs, listened to their pulses and questioned them about their lifestyles, from nutrition to bowel movements. He became, according to pacification agent Shimazaki, 'a famous doctor who was not a doctor'. Thus, Shimazaki argued, passion and effort mattered more than actual learning. ${ }^{83}$ Like medics, pacification agents gave out seirogan, a medicine used to treat diarrhoea, ${ }^{84}$ and often used iodine. In one case, an agent washed a woman's eyes with iodine diluted in water, resulting in shrieks of pain but, eventually, the return of her eyesight. ${ }^{85}$

Because of their limited knowledge and equipment, pacification agents sometimes asked military medical personnel for help, either in providing treatment or in supplying them with medicine. The agents could deal with minor ailments but not with surgical cases such as appendicitis or wounds incurred in the war. They also needed help managing epidemics, such as typhoid fever and dysentery, which the military feared and which thus warranted its direct involvement. ${ }^{86}$ It is likely that help from medical personnel was required in many other situations as well, but that it was not always available. Evidence suggests that pacification teams cooperated with other care providers as well. For example, according to one testimony, a Chinese physician who had been educated in Canada joined a pacification team, as well as a few women, who supposedly made the team particularly successful, so much so that the locals competed with each other for a checkup. ${ }^{87}$ It seems the participation of women was not common but noteworthy nonetheless. Shortly after the war broke out, the Dojjinkai, mentioned earlier, strengthened its collaboration with the military by sending medical teams to provide relief to wounded and sick Japanese and Chinese people in areas harmed by the war and supporting pacification teams in northern China. ${ }^{88}$ According to Lo, following the instruction of the Ministry of Foreign Affairs, it also sent separate designated teams to administer vaccinations and provide more general treatment in both cities and countryside. The overarching goal, as in the case of the pacification teams, was to facilitate the military's takeover of these areas. ${ }^{89}$

Despite the relative success of medical pacification and the often rosy descriptions in testimonies, it was impossible to detach medical care from the context in which it was provided. Pacification efforts usually followed military activity. It may well be imagined that the population remained suspicious of both military medics and military-affiliated pacification agents.

\section{Trust and fear}

Fujimoto Hidemi joined pacification squads as a medic in 1938 and 1939, usually comprising about 15 soldiers and 2 officers. They would set out on campaigns two to three times every month to work in villages $15-20 \mathrm{~km}$ away from their base. Most of the people Fujimoto treated suffered from a variety of ailments, since, he argued, they had never received medical care. Fujimoto described being welcomed by the population and even being treated to a feast. ${ }^{90}$ To him the campaigns were 'an important role of the military'. ${ }^{91}$ Moreover, he saw them as means to promote the military's standing in China. 'I believed that

\footnotetext{
${ }^{81}$ Aoe, op. cit. (note 59), 184; Koba, op. cit. (note 60), 106-7; Shimazaki, op. cit. (note 69), 222.

${ }^{82}$ Brook, op. cit. (note 27), 72.

${ }^{83}$ Shimazaki, op. cit. (note 69), 222-3.

${ }^{84}$ On seirogan see note 48 .

${ }^{85}$ Aoe, op. cit. (note 59), 184, 187-8.

${ }^{86}$ Aoe, op. cit. (note 59), 208, 210; Shimazaki, op. cit. (note 69), 61-2, 88-9, 118, 222.

${ }^{87}$ Aoe, op. cit. (note 59), 279.

${ }^{88}$ Hayashi Gonsuke, 'Dōjinkai shōwa jūsan-nen', 24 September 1937, JACAR reference: B05015106200.

${ }^{89}$ Lo, op. cit. (note 6), 156-8.

${ }^{90}$ Fujimoto Hidemi, Senjō ni okeru kango nisshi (Tokyo: Bungeisha, 2002), 35-7.

${ }^{91}$ Ibid., 35.
} 
one of the army's important tasks was to blend into the local population. I consequently wanted to become a non-commissioned medic officer in whom anybody would be able to trust (shinrai 信頼)' ${ }^{92}$ However, he noted that during his squad's first visit to a certain village, no young women were seen owing to 'bad things' other soldiers had done there beforehand. Only after the squads returned consistently did the women gradually come out of hiding. ${ }^{93}$

Saitō Hitoji gave another example of this coexistence of suspicion and trust. Saitō served as a unit medic in Dangyang, Hubei. His unit sent him on a pacification mission in 1942 to establish a small clinic to treat the local people. However, since the army had commandeered most of the houses in the area, the population avoided any contact with the military, including the medical clinic. As time passed, people eventually came to receive help. Consequently, Saitō argued, medical services proved to be the most successful form of pacification. ${ }^{94}$ Yet, as both testimonies reveal, it took time and persistence before the people were willing to receive care, and even then, the trust they bestowed upon their care providers seemed tentative. In the background was the inherent discrepancy between the help given by care providers and the actions of the military they represented.

The memory of violence and its consequences were sensed by both medics and pacification agents. Pacification agents were often unprepared for the havoc the military caused in China, for which they were sent to compensate. Some even left their positions in distress over the reality they encountered. ${ }^{95}$ Medics could not leave their positions, although they, too, witnessed and at times participated in traumatic events and crimes. Imazu witnessed a vivisection of a Chinese prisoner of war at the end of his medical training. As he described years later, the atrocity made him doubt the principles on which his training was based and the fundamental meaning of his role - to save human life, without distinction between friend or foe. ${ }^{96}$ The trauma remained with him his entire life. Other medical atrocities took place during the war, most famously in Unit 731, about which rumors circulated among the local population. ${ }^{97}$ And war crimes took place beyond the medical context, as has been extensively documented. ${ }^{98}$ We can imagine that such violence made the people reluctant to receive care.

Thus violence often clashed with pacification efforts. Pacification agents, although they were not officially soldiers, found that their proximity to the military and close collaboration with it made their job particularly challenging. Pacification agent Ichikawa Fujio entered an empty village in Fushan in 1939. He was sent by his unit commander to find people and thus enable the unit to collect information. In the empty village, he encountered an elderly man, who temporarily returned to find out if his home was still standing. Realising Ichikawa was Japanese, the man was apprehensive. Only when Ichikawa showed him a certificate attesting Ichikawa was a pacification agent, did the old man sigh in relief. According to Ichikawa, the man periodically came down from his hiding place in the mountains to visit his home, and the two established a friendly relationship, conversing mostly in writing. Ichikawa gave the old man a certificate stating he was a 'good citizen'. But one day, Ichikawa found the man collapsed in his house,

\footnotetext{
${ }^{92}$ Ibid., 78.

${ }^{93}$ Ibid., 35-6.

${ }^{94}$ Saitō Hitoji, Suna no shiro (Fukushima: Saitō Hitoji, 1987), 80.

${ }^{95}$ Brook, op. cit. (note 27), 61, 236.

${ }^{96}$ For a full account, see NHK interview with Imazu Shigeru. 'Hito no inochi wo sukuu eiseihei', Sensō shōgen ākaibuzu, 21 January 2011, https://www2.nhk.or.jp/archives/shogenarchives/shogen/movie.cgi?das_id=D0001100762_00000 (accessed 4 July 2020). Vivisections were decidedly not the rule in Japanese military medical training, although there are other known cases, such as the 1945 vivisection of American pilots in Kyushu University School of Medicine. See: Suzuki Akihito, 'Kyūshū daigaku igakubu jiken', Ikō Toshiya et al. (eds), Ajia taiheiyō sensō jiten (Tokyo: Yoshikawa Kōbunkan, 2015), 144. A Japanese physician who served in an army hospital in Shanxi famously testified that physicians in his hospital conducted vivisections on Chinese POWs on a regular basis: Yuasa Ken with Yoshikai Natsuko, Kesenai kioku: nihongun no seitai kaibō no kiroku (Tokyo: Nicchū shuppan, 1996, original from 1981).

${ }^{97}$ See note 20 .

${ }^{98}$ On the research and memory of war crimes, see Greg Bradsher et al. (eds), Researching Japanese War Crimes Records (Washington: National Archives and Records Administration for the Nazi War Crimes and Japanese Imperial Government Records Interagency Working Group, 2006); Joshua A. Fogel (ed.), The Nanjing Massacre in History and Historiography (Berkeley: University of California Press, 2000).
} 
brutally beaten by Japanese soldiers during questioning. Ichikawa took the man to the nearby pacification medical room, provided him with care, apologised profusely and later accompanied him halfway to his hideaway in the mountains. The man did not want to reveal its exact location, even to Ichikawa. ${ }^{99}$

This story reveals the various and oftentimes contradictory layers of the relationship between the ruler and ruled. Pacification works provided care and assistance to the population to gain its trust. The account might have exaggerated the friendly nature of Ichikawa's relationship with the older man. We may also assume that the man had his own motivations in interacting with Ichikawa, as civilians often found themselves squeezed between the Japanese and Chinese armies. Many had suffered under the Nationalist government before the war, particularly in rural areas. ${ }^{100}$ Regardless, Ichikawa's efforts to overcome the effects of violence were sabotaged by further violence waged by his own compatriots. It was not rare for Japanese soldiers to beat, burn, rape and pillage, handicapping the already challenging work of pacification. Pacification agents, like medics, noted the scarcity of women among the patients they treated, which reveals a widespread fear of sexual violence. ${ }^{101}$ Even medicine, whose intimate nature could bring people together despite the formidable context, was not omnipotent.

People sometimes feared not only the Japanese agents and medics but also the alien methods they used. Japanese care providers subscribed to medical theories and methods, which differed from local ones. According to navy officer Koba, skin diseases, ringworm and infectious diseases were prevalent among the population in the southern island he reached. He gained the cooperation of local leaders to conduct medical pacification works: teach the people about hygiene, provide medicine and administer vaccinations. Koba described strong resistance from the population, particularly towards vaccination. People feared the needles and, more important, believed that the Japanese were trying to poison them in the guise of help. When it came to non-invasive medicine, such as balms, some expressed enthusiasm and curiosity, but others expressed fear and washed off the balm upon returning home. ${ }^{102}$

Such fears were based not only on unfamiliarity but also on the reality of warfare. The Japanese military occasionally employed violent means to vaccinate the population, particularly during epidemics. It also used germ warfare in China, which exacerbated fears that the vaccination needle was actually a malicious carrier of disease. ${ }^{103}$ Accordingly, trust took time and effort to cultivate, but it was easy to break.

\section{Spontaneous encounters: medics and civilians}

Being posted in the Chinese countryside brought medics into contact with the local population not only in the ways the military planned. During the war, units often sent small forces as detachments (bunkentai 分遣隊) to strengthen the army's hold on remote areas. Testimonies reveal that civilians came to these detachments' bases on their own initiative to seek out medics. According to research, despite the severity of violence on the part of the Japanese military, members of the rural population saw Japan as just one more overlord in a long history of oppression and exploitation. ${ }^{104}$ Hence, seeking help from Japanese soldiers was not an inexplicable anomaly. However, the ensuing encounters were yet another challenge to the ever-present, delicate balance between trust and fear, medicine and violence.

\footnotetext{
${ }^{99}$ Aoe, op. cit. (note 59), 235-8.

${ }^{100}$ Rana Mitter, China's War with Japan (London: Allen Lane, 2013), 50.

${ }^{101}$ Aoe, op. cit. (note 59), 74, 221; Brook, op. cit. (note 27), $23-4$.

${ }^{102}$ Koba, op. cit. (note 60), 105-6.

${ }^{103}$ Rogaski, op. cit. (note 6), 271-2, 284; Ruth Rogaski, 'Vampires in Plagueland: The Multiple Meanings of Weisheng in Manchuria', in Charlotte Furth and Angela Ki Che Leung (eds), Health and Hygiene in Chinese East Asia (Durham: Duke University Press, 2010), 147-56.

${ }^{104}$ Barak Kushner, Men to Devils, Devils to Men (Cambridge: Harvard University Press, 2015), 24; Donald Gillin, 'Review Article: "Peasant Nationalist" in the History of Chinese Communism', The Journal of Asian Studies, 23 (1964), 281; R. Keith Schoppa, 'Patterns and Dynamics of Elite Collaboration in Occupation Shaoxing County', in David P. Barrett and Larry N. Shyu (eds), Chinese Collaboration with Japan, 1932-1945 (Stanford: Stanford University Press, 2001), 166-7.
} 
While he served in a detachment near Shangshezhen in Shanxi province in 1944, Matsumoto Masayoshi found that occasionally people from the local village, mostly its administrators, would come to see him. He conversed with them using broken Chinese and hand gestures. One day, an approximately 30-year-old woman came to seek care after being shot in the back. Matsumoto sterilised and bandaged the wound, using gauze and iodine. He believed her intestine was hurt as well, since he found millet grains as he examined the wound, but there was little more he could do. There was no doctor in the detachment to perform surgery. A month or two later, the woman returned to thank him, offering a chicken. Matsumoto looked at the wound again. Its opening had healed, but he did not know what the woman's internal condition was and he never learned what happened to her in the long run. Another time, one of the local administrators came to ask Matsumoto to come with him to the village to examine his father. Matsumoto took his medical kit and went. There were few other sources of medical care in the village:

One day I asked the Chinese administrator who came to call on me, "When you get sick, what do you do?" [He replied,] “If we are sick - meifa 沒法 [in Chinese]," there is nothing that could be done. I asked, "Is there a doctor in the village?" He replied, "There is no doctor... There is one far away, but we can't call him." "Why?" I asked. "Because if we call a doctor, we have to give him taimen [possibly 太面 in Chinese] to eat.” Taimen was made of wheat, something like udon noodles...But he explained that they had no wheat. So I asked, "What do all of you eat?" $\mathrm{He}$ replied, "Millet. Something like millet gruel"... twice a day, morning and evening. They led a very poor life. Within the mountains of Shanxi you had sorghum, some places had corn...millet these types of grains. The people of Shanxi were really poor. ${ }^{105}$

According to Matsumoto, the people in the village did not have any immediate source of medical care. The only form available required payment, which was beyond the people's means. ${ }^{106}$ Under these circumstances, people occasionally chose the Japanese army base as their answer, though Matsumoto's examples suggest they usually came only in times of emergency, and more often than not, they were people from a higher social stratum within the village.

Fujimoto Hidemi found a similar situation when he was stationed in a village in Wuchang earlier in 1939. Once, a Chinese woman brought her 10-year-old son to the base clinic. After asking the military doctor for permission, Fujimoto treated the boy's broken arm and replaced his bandages daily. A few days later, Fujimoto treated a young Chinese woman. She suffered from a very high fever. Her family brought her to the medical care room for help. Fujimoto believed she was suffering from malaria, but the military forbade the provision of quinine to anyone who was not in the military. He gave her two aspirin, instead, which lowered her fever. Fujimoto explained that many people in China never took any Western medicine, especially those living in mountainous areas. Consequently, he believed, the effect of the pills was stronger than on those who were accustomed to them. ${ }^{107}$ For Fujimoto, assisting the local people as a medic enabled him to use his skills to do good but within limits. Although quinine might have been the best thing for his patient, he worked within the restrictions of the system and provided her with an alternative, a choice he later rationalised with the medico-historical context of the region.

These examples illustrate the nature of the relationship detachments developed with adjacent villages. According to Matsumoto, the detachment base maintained peace with the village and a friendly relationship with local administrators. He also emphasised, however, that this friendliness was superficial at best, and that it was difficult to know what the people were really thinking. Considering another part of Matsumoto's testimony, it is possible to understand why. Matsumoto related that the detachment soldiers would raid nearby villages aligned with Communist forces and pillage food. According to

\footnotetext{
${ }^{105}$ Author interview with Matsumoto Masayoshi, 5 March 2014.

${ }^{106}$ Henrietta Harrison's analysis of a diary written by a man who lived in the same Shanxi province reveals a similar frustration with doctors' expectations of meals during patient visits. Harrison, op. cit. (note 54), 56.

${ }^{107}$ Fujimoto, op. cit. (note 90), 26-9.
} 
Matsumoto, in most of these operations, the villagers anticipated the raid and fled beforehand, leaving their belongings and livestock behind. This was especially true of women. On one of these raids, however, around seven women did not escape in time. The soldiers captured them and took them back to the detachment. ${ }^{108}$

Matsumoto's role as detachment medic was to prevent disease. Diseases were often location-specific, but like other armies, the Japanese military made particular efforts to prevent the spread of venereal diseases. ${ }^{109}$ Medics were part of this effort. They provided soldiers with condoms, ointments and explanations of sexual hygiene. ${ }^{110}$ Fujimoto and Ikeda, the medics quoted above, also periodically went to 'comfort stations' to examine the women there. ${ }^{111}$ As Ikeda noted, 'from the viewpoint of disease prevention, the comfort stations were under the jurisdiction of the base clinic'. ${ }^{112}$ Since Matsumoto was in charge of maintaining the health of the detachment soldiers, the kidnapped women were within his responsibility as potential sources of disease: 'My job was to examine the women for venereal disease, because I was a medic. So I checked them, gave the soldiers condoms and told them, "Be careful"'. ${ }^{13}$ Gynecology and female anatomy were not parts of medic training, since medics were supposed to treat the male soldier. However, life in China and, later on, in Southeast Asia, changed that. When Matsumoto was posted in his unit headquarters in Yuxian before setting out to the detachment, he distributed condoms to soldiers every Sunday, their day off. Additionally, he assisted the unit physician once a month in examining roughly six 'comfort women' who accompanied his battalion. He learned rudimentary examination procedures through observation. The physicians themselves were not gynecologists, and two of the three were fresh out of medical school. Thus, it is perhaps not surprising that Matsumoto did not remember finding any case of infection:

Venereal disease could mean different things - gonorrhea, syphilis etc. But we didn't have a microscope, so the examinations did not reach the extent of determining which bacteria it was. We just looked (and assessed) - 'This looks clean', or 'This looks strange'. The doctors would make the suitable judgment call. ${ }^{114}$

\footnotetext{
${ }^{108}$ Author interview with Matsumoto Masayoshi, 5 March 2014. Matsumoto shared his memories on a number of occasions, including with the foreign press. As in other similar cases, his testimony was subject to backlash. See, e.g., an interview with BBC News Japan: Rupert Wingfield-Hayes, 'Japan Revisionists Deny WW2 Sex Slave Atrocities', BBC News, 3 August 2015, http:// www.bbc.com/news/world-asia-33754932 (accessed 8 July 2020). See also David McNeill, “'If We Do not Face our Past, We're Bound to Repeat the Same Mistakes." Japanese Wartime Medical Orderly Reports on Army's Role in Maintaining “Comfort Women" System', Japan Focus, 12, 42 (2014), http://apjjf.org/2014/12/42/David-McNeill/4202.html (accessed 8 July 2020).

${ }^{109}$ In 1934 , the Japanese military minister even shared with the military attaché of the French embassy in Japan a detailed report on preventive measures the Japanese military developed. See 'Fukoku bukan yori guntai ni okeru karyūbyō yobō ni kanshi toiawase no ken', October 1934, JACAR reference: C01006593500.

${ }^{110}$ Eiseihō oyobi kyūkyūhō, authorised by Kawashima Yoshiyuki (Tokyo: Kobayashi Matashichi, 1936, reprints through 1944), 34-5.

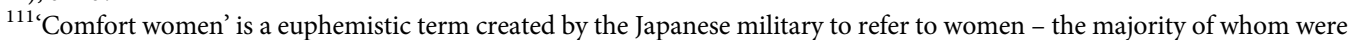
Korean - who provided or, as often argued, were forced to provide, sexual services to countless Japanese soldiers. It is generally argued that most militaries were historically accompanied by the brutal abuse of women through prostitution and violent rape, yet the Japanese military systematised the abuse on a large scale. The historical memory of 'comfort women' has become a topic of great political and social controversy in contemporary Japan and beyond, particularly, in South Korea. While historical research on the topic originated in Japan, various groups - civilian, academic and political - deny it on various grounds, such as the number of women, the way they were enlisted, the degree of coercion involved and the validity of oral testimonies. Much has been written on the topic. See, for instance, Yoshimi Yoshiaki, Jügun ianfu (Tokyo: Iwanami Shoten, 1995), translated into English by Suzanne O’Brien as Comfort Women: Sexual Slavery in the Japanese Military during World War II (New York: Columbia University Press, 2000); George Hicks, The Comfort Women (New York: W.W. Norton \& Company, 1995). On the Chinese context, see Peipei Qiu, with Chen Lifei and Su Zhiliang, Chinese Comfort Women: Testimonies from Imperial Japan's Sex Slaves (Oxford: Oxford University Press, 2013). On memory and politics see, for instance, Hayashi Hirofumi, Nihongun 'ianfu' mondai no kakushin (Tokyo: Kadensha, 2015).

${ }^{112}$ Fujimoto, op. cit. (note 90), 41-2; Ikeda, op. cit. (note 40), 14.

${ }^{113}$ Author interview with Matsumoto Masayoshi, 5 March 2014.

${ }^{114}$ Ibid.
} 
According to Matsumoto, about a week after the kidnapping, the detachment commander told the soldiers it was time to let the women return to their village. However, following detachment orders, the village head came to the detachment with two women, whom Matsumoto believed were prostitutes, in exchange. Matsumoto checked them for venereal disease, gave the soldiers condoms and, as before, told them to 'be careful'. The soldiers released the two women following the Japanese defeat in the war in August 1945. ${ }^{115}$

Testimonies like Matsumoto's reveal the confluence of violence and benevolence. Matsumoto helped the local population on different occasions, and his and Fujimoto's accounts reveal that, in some cases, women did appear at the base and ask for help. However, the kidnapped women are a reminder that these small moments of humanity existed within a violent war of occupation in which medicine also played an aggressive role. As medic, Matsumoto impressed a medical stamp upon sexual violence. Even in less extreme examples, a distinction consistently remained between the two groups of patients. If, for instance, Matsumoto had suspected that a soldier's wound extended to his intestines, he most probably would have sent him to a hospital to be treated by a doctor. This was not the case with the local Chinese woman. There were cures for civilians and other cures for soldiers. Thus, in all cases, medics succeeded in cultivating a certain degree of trust, but it was restricted by circumstances and consequently elusive and tentative.

The above examples took place while medics were settled in the countryside. Miyayama Suezo described a different encounter sometime between 1942 and 1943, while he was serving as a unit medic during a campaign in Yingde, Guangdong. ${ }^{116}$ As his unit advanced, it created encampments to prevent Chinese forces from returning. Miyayama spent his time in a tent he set up to treat the unit's wounded soldiers. It was the beginning of the rainy season, and he wanted to spread some material on the soaked floor of the tent. He went in search of such material in a small shed nearby. When he opened the door, he found five or six women hiding in the shed with a newborn baby in a basket. As he took in the scene, Miyayama quickly realised what must have happened. As Matsumoto also noted, the inhabitants of a village or town would usually flee before the Japanese army entered the territory - women in particular. It seemed one of the fleeing women had gone into labor and hidden in the small shed with a few others. The women were very alarmed and yelled out when they saw Miyayama. He did not understand what they were saying but eventually managed to decipher a few words he had memorised beforehand, specifically $i$-san (イーサン, doctor). It is probable that when the women saw the Red Cross insignia on his arm, they believed he was a doctor. Miyayama examined the baby, starting with the eyes, which he sterilised to prevent trachoma. He had little experience beyond his military medical training and occasional observations of the one doctor in his battalion. Moreover, though trachoma was one of the diseases included in medic training, he had never learned how to care for babies. ${ }^{117}$ One can read between the lines how tense Miyayama probably felt and how alarmed the women were. After he completed the examination and ascertained that the baby was healthy, everyone in the room felt relieved. Miyayama believed it calmed the women to see a soldier who liked babies.

Miyayama's narrative differs from the others. As noted, his interaction took place while on a campaign and not at a detachment. Additionally, although the women requested his help, the encounter between the caregiver and patient took place unexpectedly and was coloured by anxiety. Miyayama noted, 'I was taught that medicine was a benevolent art (jinjutsu 仁術)... Therefore, I decided that even though they were Chinese, I would provide the best treatment I could'. In other words, Miyayama possibly had a moment of deliberation, even if fleeting. The women themselves, he noted, knew the Japanese military included medical personnel, from whom they could request help if needed, but not

\footnotetext{
${ }^{115}$ Ibid.

${ }^{116}$ Miyayama related this account in correspondence with the author over a period of a few months. This incident was shared in a letter he sent the author in March 2014. Miyayama did not specify dates, but based on his age and his description of the incident, it likely took place in late 1942 or early 1943.

${ }^{117}$ Kawashima, op. cit. (note 110), 35-6.
} 
necessarily during a campaign. Eventually, his medical skills broke the tension. Nonetheless, the next day, the women were already gone.

In all examples of benevolent encounters, the medic remained an occupying soldier. One element that epitomised the gap between medics and their patients was the language they used. All of the medics memorised some local words but were far from fluent. In most cases, the soldiers combined the little they knew with hand gestures, but the barrier of understanding remained, especially considering the various dialects and languages they encountered in China. The medic was to adapt to a different population linguistically and medically, caring for those he was not trained to treat. The population was apprehensive, particularly women. And yet, despite the barriers, medical skills created a different kind of space that allowed the establishment of a guarded trust. Such achievements served the army's pragmatic goals of pacification, but they were arguably also moments of medical humanism in violent surroundings.

\section{Conclusion: small moments of humanity}

Behind the framework of occupation were people, both occupiers and occupied. Building and maintaining an occupation entailed building a relationship between members of the ruling army and the ruled population. This relationship was coloured by violence but also by mundane human interactions as the army moved within the Chinese countryside. Medicine was a vehicle for promoting benevolent moments and cultivating trust between the occupier and occupied. In the empire, caregivers were often a mix of Japanese and local civilians, but in the Chinese countryside, they were typically associated with the Japanese military. Medics were soldiers trained by the army in medical care, and their authority depended on their military rank and status. Pacification agents were civilians affiliated with the army, whose purpose was to facilitate military activity using various means, including medicine. Their double yet intertwined identity as representatives of the military and as caregivers resulted in multivalent relationships with members of the local Chinese population, as well as with other soldiers.

The provision of medical care by the Japanese military to local populations in wartime did not originate in the War in China nor did its use for promoting values that the Japanese military and state wished to promote. During both the Sino-Japanese War of 1894-1895 and the Russo-Japanese War (1904-1905), the Japanese military and Red Cross provided medical treatment and care for Qing army soldiers and Russian prisoners of war, respectively, accounts of which were widely disseminated through woodblock prints, photographs, war reporting and foreign observers. ${ }^{118}$ Particularly during the widely covered Russo-Japanese War, the Japanese military cultivated an image of humanitarianism; it went beyond the Geneva Convention, which Japan had signed not long before, in 1886, and excelled in humanitarianism, surpassing Western militaries of the time. Yoshiya Makita reveals that, during the same war, the Japanese Red Cross also used army hospitals and opened clinics in order to provide free treatment to the local population in northeastern China and to improve sanitary conditions in the area. Its aim, according to Makita, was not only to prevent disease and strengthen the military's control over the population but also to demonstrate to the world the Chinese population's perceived inferiority and Japan's civilised, superior nature, thus legitimising Japan's presence in the area. The object of care was the local population, but the target audience was the Western powers. ${ }^{119}$ Similarities exist between these earlier cases and the ones discussed in this article, and direct points of continuity remain to be explored. However, the cases analysed here were fundamentally different, since the Western powers were no longer the target audience for what was, at least in part, a medical performance. Now the target and object were

\footnotetext{
${ }^{118}$ Judith Fröhlich, 'Pictures of the Sino-Japanese War of 1895-1895', War in History, 21, 2 (2014), 243-8; Kita Yoshio, "'Bunmei no sensō" to shite no nisshin sensō', in Kawai Toshinobu and Kurosawa Fumitaka (eds), Nihon sekijūjisha to jindō enjo (Tokyo: Tokyo daigaku shuppankai, 2009), 65-86; Kita Yoshio, 'Junebu jōyaku teiyaku kokukan no nichiro sensō', in Kawai and Kurosawa, 105-39; Yoshiya Makita, 'The ambivalent enterprise: Medical activities of the Red Cross Society of Japan in the Northeastern Region of China during the Russo-Japanese war', in Dan Ben-Canaan, Frank Grüner and Ines Prodöhl (eds), Entangled Histories: the Transcultural Past of Northeast China (New York: Springer, 2014), 189-96.

${ }^{119}$ Makita, op. cit. (note 118), 196-203.
} 
the same - medical care for the local Chinese population was not a performance for outside eyes but a space of intimacy to cultivate trust within.

The article centered on several forms of trust that the Japanese military tried to use interchangeably, harnessing one to facilitate the other. The trust that the military recognised as key to medical care - so much so that it sought to cultivate it within the military through shared experience and differential rankbecame a tool for consolidating occupation. The military wished to transmute medical trust towards the caregiver created during the medical encounter into a broader trust towards the Japanese military and polity at large. Thus medicine was intended to encourage collaboration. These attempts bore fruit, according to various testimonies, as a result of the intimate and vulnerable nature of the medical encounter, a powerful opportunity for the military to demonstrate magnanimity. Thus, medicine was a 'tool of empire' but in a different sense than in historical accounts of Taiwan and Korea. ${ }^{120}$ There, as described in the introduction, medicine and public health facilitated Japanese colonial rule by creating an epidemiologically safe environment for the Japanese population and only secondarily for the local populations. In this article, by contrast, we saw that curing the bodies of the populace in China served as a tool for emotional mobilisation, by cultivating a willingness among the occupied to cooperate with the occupier.

The article argued that the success of such encounters was neither easy to achieve nor longstanding, given the context in which they took place. Trust clashed with violence and the resulting fear. Serving as soldiers or affiliates of an occupying army that raided, raped, commandeered and even used medicine as a tool of violence, medics and pacification agents found it challenging to cultivate enduring trust. Actions and emotions were distinct. Even when cooperation took place, it did not signify the existence of a mutual trust of any depth. Moreover, it was possible for a patient to trust the caregiver in the context of the medical encounter and still suspect the Japanese military as an institution. The article showed how the military both committed atrocities and extended a helping hand.

Planned and unplanned medical encounters were also a site of confrontation between different medical traditions and beliefs. As testimonies repeatedly noted, the military typically arrived in areas where the population had little or no access to medical care. Japanese caregivers were trained in methods and concepts following scientific, laboratory-based medicine, originating in the Meiji era reforms. Though they were limited in their means and expertise, medics and pacification agents used stethoscopes, explained disease with concepts such as germs, used pharmaceutical medicaments, called for antiseptic surgery when possible, explained hygiene and administered vaccinations. Many of the local people had never been exposed to these concepts or methods. On the one hand, Japanese testimonies described how people welcomed the help because they had no alternative and because, on certain occasions, they witnessed the effectiveness of the foreign methods. On the other hand, these testimonies also preserve echoes of local voices that were not always grateful and welcoming, indeed were often suspicious. These suspicions were mainly due to the association of medical care with the Japanese military, but also to their unfamiliar nature, as in the case of vaccinations. Fear, too, took a variety of forms.

The variety of 'trusts' and 'fears' reveals that medicine played diverse roles during the War in China. It was first and foremost a site of interaction between people where different goals, languages, belief systems, emotions and hierarchies intertwined. It was not singularly a pragmatic tool of occupation, a form of atrocity or pure benevolence, but a mixture of all. Though authored only by the occupiers, the testimonies presented in the article conveyed the loaded nature of these medical encounters, the power

\footnotetext{
${ }^{120}$ The term 'tools of empire' originates in Daniel Headrick's classic work The Tools of Empire: Technology and European Imperialism in the Nineteenth Century (Oxford: Oxford University Press, 1981). Headrick highlights the role of science, technology and medicine in facilitating the vast expansion of modern imperialism. Medicine specifically rid the colonisers of disease, particularly malaria. Other works have added to and qualified this interpretation. In the case of the Japanese empire, Liu, for instance, notes that medical reform did not precede but rather took place during and, in certain respects, as a result of colonial expansion, that it served multiple purposes and that it was not solely a top-down affair, but also involved local participation and learning from local customs. Liu, op. cit. (note 6), 7-8, 64-73, 131-2, 165-8.
} 
imbalance between the parties and the potential for taking advantage of this imbalance. They also revealed small moments of humanity, where medicine could serve as a bridge, even if an unstable one.

Acknowledgements. First and foremost, I would like to thank the men who were willing to share their precious and painful life stories with me. Without them, this article would not have been possible. Deep gratitude to the people who had enough faith in me to facilitate the interviews: Ishikawa Hiroshi, Tomita Tomoaki, Gotō Motoyuki, Nakamura Eri, Asakawa Tamotsu, Tadokoro Satoko and the volunteers of the Senjō taiken hōei hozon no kai. I owe profound thanks to Suzuki Akihito, who encouraged me to enter the oral history world in the first place and supported me throughout. To Sheldon Garon, Benjamin Elman, Asaf Goldschmidt and Watanabe Yutaka, for their longstanding guidance and support. Very special thanks to Mike Liu, Tina Johnson and James Cook. I am also grateful to Suzuki Noriko, Kimura Masuo, Nicole Barnes, Ori Sela, Angharad Fletcher, Orly Lewis, Danny Orbach, Ken Daimaru, Aron Shai, super editor Gilly Nadel, Ming Gao and above all Ehud and Ruti Harari. Final thanks to Sanjoy Bhattacharya, Arnab Chakraborty and the anonymous reviewers for their valuable comments and attention to details. In such busy and abnormal times, it is not to be taken for granted. The people mentioned above have been invaluable sources of information, encouragement and assistance crucial for this project, but the responsibility for any inaccuracy, misinterpretation or mistake is entirely my own. 